\title{
Jakob-Creutzfeldt Disease
}

\author{
J.M.S. Pearce \\ Emeritus Consultant Neurologist, Department of Neurology, Hull Royal Infirmary, Hull, UK
}

Creutzfeldt-Jakob disease (CJD) is a transmissible spongiform encephalopathy. It is characterised pathologically by neuronal loss, spongy changes in the grey matter and an astrocytosis, and clinically by rapidly progressing dementia, pyramidal and extrapyramidal disease with myoclonus and triphasic discharges in the electroencephalogram. This dreaded fatal illness remained mysterious in its cause until Pruisner's exciting discovery of proteinaceous infectious particles, which could replicate themselves, though they had no nucleic acid [1]. They became known as prion proteins. Pruisner justly received the Nobel Prize in 1997.

Historically, Westphal [2] had introduced the term 'spastic pseudosclerosis' in 1883, in patients with disseminated sclerosis. It was for a time thought to be a variety of Wilson's disease, but Wilson rightly objected. It was then confused with CJD when in 1921, Alfons Jakob described 4 cases of: 'spastic pseudo-sclerosis, disseminated encephalomyelopathy' [3]. He acknowledged earlier work, including Creutzfeldt's case [4]. Jakob published a fourth case in the same year, 'resembling pseudosclerosis.' His fifth case appears in his 1923 book The Extrapyramidal Diseases [5]. He classed them all as 'spastic pseudosclerosis'. Creutzfeldt confirmed that Jakob's 3 cases were identical, and included them $[4,6]$.

In 1913, while working at Alzheimer's clinic, Creutzfeldt studied a 'new and unusual type of neurological disease' in a 22-year-old woman who had developed an ataxic gait at the age of 16 . Her mother died of unknown cause at the age of 56, and 2 siblings were mentally defective. She had spastic pyramidal signs, tremors and became ataxic and demented. She developed a symmetrical rash affecting her face, later also both hands, groin and both feet. While on a dermatology ward, she had a 'hysterical seizure' with arc de cercle. All of her symptoms, including the gait disorder improved. One year later, her gait deteriorated. She refused to eat or wash, and showed agitated paranoid behaviour and inappropriate laughter. Temperature was $38.9^{\circ} \mathrm{C}$; she was disorientated with staccato speech. She had myoclonic limb jerks, intention tremor, nystagmus, increased tone, brisk reflexes, hyperaesthesia and hyperalgesia. Over 3 months, she deteriorated and died in status epilepticus with tonic seizures, some with Jacksonian march, and myoclonus. Creutzfeldt's detailed pathology does not mention spongiform change or plaques (a hallmark of variant CJD). The brain showed moderate atrophy, patchy neuronal loss, gliosis and degeneration of both corticospinal tracts. The pathology, familial mental retardation, her remitting course and rash make improbable either 'variant' or sporadic CJD.

Jakob's third patient was a 42-year-old man with vertigo, and later weakness of his legs, dysarthria, diplopia, ataxia and dementia. He became stuporose 9 months after the onset and died. Like Creutzfeldt, Jakob found microscopical diffuse abnormalities but no record was made of neuronal vacuolation or spongiform change. Creutzfeldt's slides unfortunately disappeared during World War II $[7,8]$.

Jakob was to examine 2 further cases. The first in the 44-year-old man Paul Bacher. His maternal grandmother and 8 of her siblings had died of unexplained cerebral disease, as eventually did his sister. Paul Bacher's autopsy, and that of the sister, and 2 of his children showed the spongiform changes, typical of CJD. These observations

\section{KARGER \\ Fax +41613061234 \\ E-Mail karger@karger.ch}

www. karger.com
(C) 2004 S. Karger AG, Basel

0014-3022/04/0523-0129\$21.00/0

Accessible online at:

www. karger.com/ene
J.M.S. Pearce

304 Beverley Road

Anlaby, East Yorks HU10 7BG (UK)

E-Mail jmspearce@freenet.co.uk 
Fig. 1. Annual incidence of CJD in the period between 1985 and 2000.

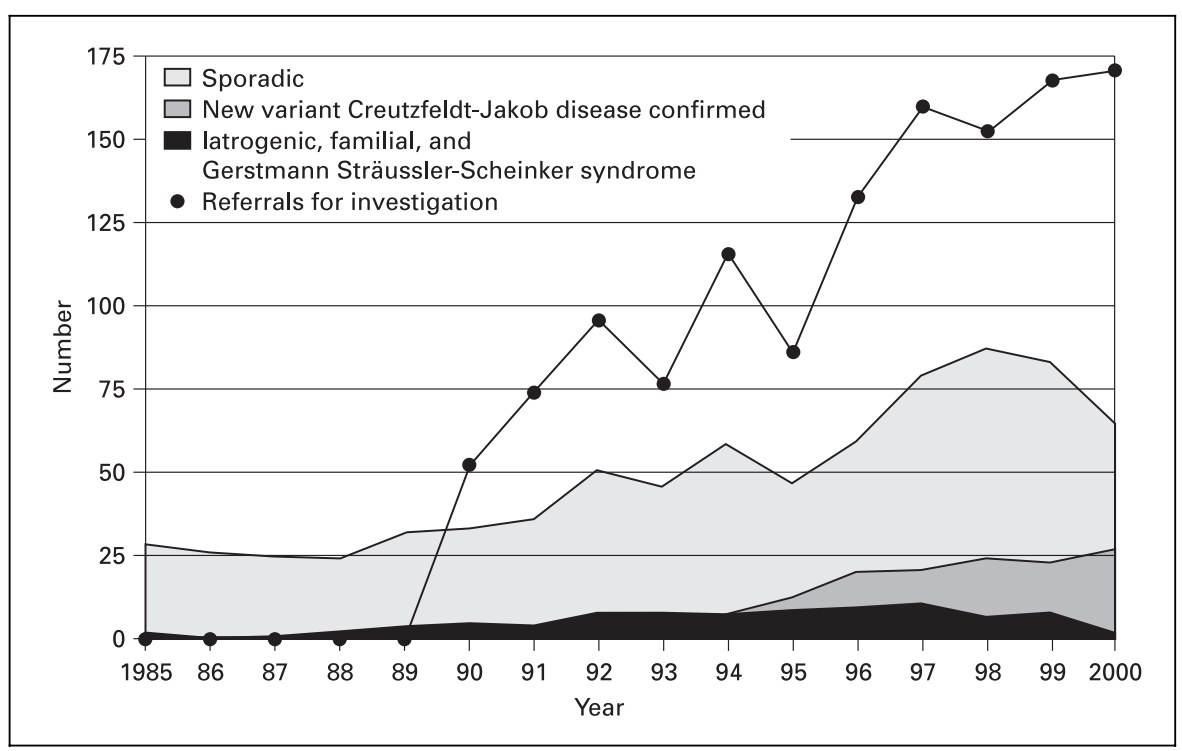

established a familial group with dominant transmission. Masters, Gajdusek, and Richardson [9] re-examined Jakob's cases, and confirmed the diagnosis of CJD only in cases 3 and 5. They showed the cardinal vacuolation of the cerebral cortex and cerebellum, and these are probably the only definite cases amongst those recorded by Creutzfeldt and Jakob. In 1994, Brown et al. [10], using DNA from a slide of one of Jakob's original Bacher family, confirmed a PRNP gene mutation.

In 1929, Heidenhain [11] reported 3 patients; 2 had cortical blindness with prominent spongy changes. These became known as the Heidenhain variant, though their nosological place is now less certain.

The nature and transmissibility of the suspected infectious agent was uncertain. However, Carleton, Gajdusek and Zigas [12] in 1957 studied kuru in cannibal patients in New Guinea; kuru was similar to scrapie in sheep. Gajdusek et al. [13] later transmitted kuru to chimpanzees in 1966, for which Gajdusek alone received the 1976 Nobel Prize $^{1}$. In 1968, Gibbs et al. [14] transmitted the disease to chimpanzees from brain tissue from human CJD patients. The link was thus forged.

Hadlow [15] importantly noted the similarity between the pathology of the brain in kuru and scrapie. This led to Prusiner's Nobel Prize winning discovery of the prion diseases [16] in 1982.

The epidemic of bovine spongiform encephalopathy (BSE or mad cow disease) in the 1990s (fig. 1) has gener-

1 Sadly, Gajdusek was later publicly discredited. ated a new variant in younger patients with a predominantly psychiatric onset [17]. That BSE is the cause of variant CJD has since been accepted, by the distinctive molecular features [18-20], but not conclusively proved. It is of interest that Creutzfeldt's case was aged 22 and 2 of Jakob's were aged 42 and 44; thus, age is not a reliable distinction. PRNP mutations show that GerstmannStraüssler-Scheinker syndrome and fatal familial insomnia are other prion disease variants of CJD.

Hans-Gerhard Creutzfeldt (1885-1964) was born in Hamburg, on June 2, 1885, the son of Dr. Otto Creutzfeldt. He read medicine in Jena, Rostock and Kiel qualifying in 1908 [21]. He wrote his thesis on pituitary tumours and studied neuropathology with Edinger in Frankfurt am Main and with Alzheimer in Breslau. He was a German naval medical officer in World War I. After the war, Creutzfeldt worked with Spielmeyer in Munich and with Siemerling in Kiel. He moved to the Charite Hospital in Berlin working with Karl Bonhoeffer. But, after 14 years, he returned to Kiel in 1938 to become emeritus professor and director of the university psychiatric and neurological division until 1953. He then worked until retirement in 1955 at the Institute of Psychiatry, Munich. Creutzfeldt was a reserved modest man and a devout Christian. On December 30,1964, he died at the age of 80 after a long illness [22].

Creutzfeldt and his family showed both great moral courage and considerable intellectual endowments in the field of medicine. Unlike many academics, who enjoyed the spoils of allegiance to Hitler and Nazism, Creutzfeldt 
used his clinic as a refuge for those who had fallen foul of the 'hereditary laws'. The Nazis imprisoned his wife, and his home and clinic were destroyed. After the war, he became rector of the Christian-Albrecht University of Kiel. His son Harald defected from the German navy to join the Dutch underground resistance. Harald was commissioned in the British Army and spent the last 20 years of his life in England [23].

Hans-Gerhard Creutzfeldt's son Otto became director of the Max-Planck Institute of Neurobiology in Göttingen, where another son Werner, was professor and chairman of the Department of Medicine.

Alfons Maria Jakob (1884-1931) was born on July 2, 1884, in Aschaffenburg am Main, son of a shopkeeper. He read medicine at the Universities of Munich and Berlin, and qualified in Strasburg in 1909. His thesis was on the pathogenesis of pseudobulbar paralysis.

He was described as 'diligent, conscientious, clinically talented, scientifically motivated and of humane, amiable and optimistic disposition'. Jakob accepted the invitation to work at the Friedrichsberg State Hospital in Hamburg, in November 1911. He worked in the pathological-anatomical laboratory led by Theodor Kaes, and succeeded him as prosector in 1913.
In the First World War, he served as physician at the front in Flanders, returning at the end of hostilities to Friedrichsberg. Jakob wrote 5 significant books and a host of scientific papers that included: cerebral syphilis, epilepsy, experimentally induced trauma and secondary degeneration, post-concussive degeneration of nerve fibres in the cord (which developed into a bible for neuropathologists) [24]. Pseudobulbar palsy, yellow fever, leprosy, 'glial nodule encephalitis' ('subacute sclerosing panencephalitis'), diffuse and disseminated sclerosis, muscular dystrophy and extrapyramidal diseases were other distinguished publications.

He trained many future famous neuropathologists among whom was Kirschbaum [8]. From the age of 40, Jakob suffered from chronic osteomyelitis, later complicated by a retroperitoneal abscess and ileus from which he died after surgery, on October 17, 1931, at the age of 47 years.

Creutzfeldt-Jakob disease is the usual eponym [25] in use, since Creutzfeldt certainly gave the earlier account. But Kirschbaum, in view of Jakob's larger contribution, reasonably argued that the correct designation should be Jakob-Creutzfeldt disease [26], and thus entitled his book.

\section{References}

1 Prusiner S: Novel proteinaceous infectious particles cause scrapie. Science 1982;216:136-144.

$\checkmark 2$ WestphalC: Über eine dem Bilde der cerebrospinalen grauen Degeneration ähnliche Erkrankung des centralen Nervensystems ohne anatomischen Befund, nebst einigen Bemerkungen über paradoxe Contraction. Arch Psychiatr Nervenkrankheit 1883;14:87-134.

3 Jakob A: Über eigenartige Erkrankungen des Zentralnervensystems mit bemerkenswerten anatomischen Befunden (spastische Pseudosklerose-Encephalomyelopathie mit disseminierten Degenerationsherden). Z Ges Neurol Psychiatr 1921;64:147-228.

4 Creutzfeldt H: Über eine eigenartige herdförmige Erkrankung des Zentralnervensystems. Z Ges Neurol Psychiatr 1920;57:1-18.

5 Jakob A: Die Extrapyramidale Erkrankungen. Berlin, Springer, 1923, pp 218-245.

6 Creutzfeldt H: Über eine eigenartige herdförmige Erkrankung des Zentralnervensystems. Vorläufige Mitteilung. Z Ges Neurol Psychiatr 1920;57:1-18.

7 Van Rossum A: Spastic pseudosclerosis (Creutzfeldt-Jakob disease); in Vinken PJ, Bruyn GW (eds): Handbook of Clinical Neurology. Amsterdam, North Holland, 1968, vol. 6, pp 726-760.

8 Kirschbaum W: Jakob-Creutzfeldt Disease. New York, Elsevier, 1968.

9 Richardson EP: Introduction to myoclonic dementia; in Rothenberg D, Hochberg F (eds): Neurological Classics in Modern Translation. New York, Hafner Press, 1977.

10 Brown P, Cervenakova B, Boellaard J, et al: Identification of a PRNP gene mutation in Jakob's original Creutzfeldt-Jakob disease family. Lancet 1994;344:130-131.

11 Heidenhain A: Klinische und anatomische Untersuchungen über eine eigenartige anorganische Erkrankung des Zentralnervensystems im Praesenium. Z Ges Neurol Psychiatr 1929;118: 49-114.

12 Gajdusek DC, Zigas V: Degenerative disease of the central nervous system in New Guinea. The endemic occurrence of 'kuru' in the native population. N Engl J Med 1957;257:974-978.

13 Gajdusek D, Gibbs C Jr, Alpers M: Experimental transmission of a kuru-like syndrome to chimpanzees. Nature 1966;209:794-796.

14 Gibbs C Jr, Gajdusek D, Asher D, et al: Creutzfeldt-Jakob disease transmission to the chimpanzee. Science 1968;161:388-389.

15 Hadlow W: Scrapie and kuru. Lancet 1959; ii:289-290.

16 Prusiner S: Novel proteinaceous infectious particles cause scrapie. Science 1982;216:136144.

17 Ironside J, Lowman A: New variant Creutzfeldt-Jakob disease. Adv Clin Neurosci Rehabil 2002;1:6-8.
18 Will RG, Ironside JW, Zeidler M, Cousens SN, Estibiero K, Alperovitch A, et al: A new variant of Creutzfeldt-Jakob disease in the UK. Lancet 1996;347:921-925.

19 Collinge J, Sidle KC, Heads J, Ironside J, Hill $\mathrm{AF}$ : Molecular analysis of prion strain variation and the aetiology of 'new variant' CJD. Nature 1996;383:685-690.

20 Bruce ME, Will RG, Ironside JW, McConnell I, Drummond D, Suttle A, et al: Transmissions to mice indicate that 'new variant' CJD is caused by the BSE agent. Nature 1997;389: 498-501.

21 Obituary. Med Klin 1965; 14:553.

22 Laux I: In memoriam. Hans-Gerhard Creutzfeldt. Med Klin 1965;60:553-554.

23 Poser CM, Bruyn GW: Creutzfeldt-Jakob Disease; in Koehler P, Bruyn G, Pearce JMS (eds): Neurological Eponyms. New York, Oxford University Press, 2000, pp 283-291.

24 Jakob AM: Normale und pathologische Anatomie und Histologie des Grosshirns. Leipzig, Deuticke, 1927-1929.

25 Spielmeyer W: Die histopathologische Forschung in der Psychiatrie. Klin Wochenschr 1922;1:1817-1819.

26 Katscher F: It's Jakob's disease, not Creutzfeldt's. Nature 1998;393:11. 